\title{
Systematic Review \\ The Impact of GLP1 Agonists on Bone Metabolism: A Systematic Review
}

\author{
Ioanna Daniilopoulou ${ }^{1}\left(\mathbb{D}\right.$, Eugenia Vlachou ${ }^{1, *}$, George I. Lambrou ${ }^{2} \oplus$, Anastasia Ntikoudi ${ }^{1}$, Eleni Dokoutsidou ${ }^{1}$, \\ Georgia Fasoi ${ }^{1}$, Ourania Govina ${ }^{1}$, Anna Kavga ${ }^{1} \mathbb{D}$ and Athanasios N. Tsartsalis ${ }^{3, *}$
}

1 Department of Nursing, School of Health Sciences, University of West Attica, Ag. Spydironos 28, 12243 Athens, Greece; ioannadaniil88@hotmail.com (I.D.); nastaziantikoudi@gmail.gr (A.N.); edokout@uniwa.gr (E.D.); gfasoi@uniwa.gr (G.F.); ugovina@uniwa.gr (O.G.); akavga@uniwa.gr (A.K.)

2 Choremeio Research Laboratory, First Department of Pediatrics, National and Kapodistrian University of Athens, Thivon \& Levadeias 8, 11527 Athens, Greece; glamprou@med.uoa.gr

3 Department of Endocrinology Diabetes and Metabolism, Naval Hospital of Athens, Dinokratous 70, 11521 Athens, Greece

* Correspondence: evlachou@uniwa.gr (E.V.); ttsartsal@yahoo.gr (A.N.T.); Tel./Fax: +30-210-746-7427 (E.V.)

Citation: Daniilopoulou, I.; Vlachou, E.; Lambrou, G.I.; Ntikoudi, A.; Dokoutsidou, E.; Fasoi, G.; Govina, O.; Kavga, A.; Tsartsalis, A.N. The Impact of GLP1 Agonists on Bone Metabolism: A Systematic Review. Medicina 2022, 58, 224. https:// doi.org/10.3390/medicina58020224

Academic Editor: Ioannis Ilias

Received: 15 December 2021

Accepted: 28 January 2022

Published: 2 February 2022

Publisher's Note: MDPI stays neutral with regard to jurisdictional claims in published maps and institutional affiliations.

Copyright: (C) 2022 by the authors. Licensee MDPI, Basel, Switzerland. This article is an open access article distributed under the terms and conditions of the Creative Commons Attribution (CC BY) license (https:// creativecommons.org/licenses/by/ $4.0 /)$.

\begin{abstract}
Background and Objectives: The association between diabetes mellitus and increased risk of bone fractures has led to the investigation of the impact of antidiabetic drugs on bone metabolism. Glucagon-like peptide-1 receptor agonists (GLP1RAs) are a relatively novel and promising class of anti-hyperglycemic drugs. In addition to their blood glucose lowering action, GLP1RAs seem to have additional pleiotropic properties such as a beneficial skeletal effect; although the underlying mechanisms are not completely understood. The present systematic review summarizes current evidence about GLP1RAs and their effects on bone metabolism and fracture. Methods: An extensive literature search was conducted based on electronic databases namely, PubMed, Google Scholar and Cochrane Central Register of Controlled Trials (CENTRAL) through October 2019 to January 2020 for articles related to bone mineral density, diabetes mellitus and GLP1RAs. We included articles published in English. Finally, we included four randomized controlled trials, three metaanalyses, a case-control study and a population-based cohort analysis. Results: Based on the articles included, the animal studies indicated the salutary skeletal effects of GLP1RAs in opposition to what has been commonly observed in human studies, showing that these agents have no impact on bone mineral density (BMD) and the turnover markers. Moreover, it was demonstrated that GLP1 was not associated with fracture risk as compared to other anti-hyperglycemic drugs. Conclusions: Findings from this systematic review have demonstrated the neutral impact of GLP1RAs on BMD. Moreover, further double-blind randomized controlled trials are needed to draw more meaningful and significant conclusions on the efficacy of GLP1RAs on BMD.
\end{abstract}

Keywords: GLP; GLP1RAs; bone mineral density; diabetes mellitus

\section{Introduction}

\subsection{Glucagon-Like Peptide 1 (GLP1) and Bone Metabolism}

Patients with diabetes mellitus are at an increased risk of fragility fractures [1]. Although many experimental studies have reported an association between diabetes and the risk of fracture, the connection between diabetes and osteoporosis has not been clarified [2]. Normal bones are constantly renewed through the process of breaking down old bone and generating new. The balance between breaking down and reformation is important for healthy bones [3]. The process of bone formation and bone resorption is called bone metabolism, in which the receptor activator of nuclear factor- $\mathrm{k} B$ ligand (RANKL)/ receptor activator of nuclear factor- $\mathrm{B}$ (RANK)/osteoprotegerin (OPG) pathway is the most crucial. Bone formation is performed by stimulating osteoblasts and inhibiting osteoclasts. Bone resorption is performed by an active osteoclast and stimulated by RANKL. RANKL is a 
cytokine belonging to the Tumor Necrosis Factor (TNF) family. This factor connects to RANK receptor in osteoclast progenitor cells and leads to differentiation and activation of osteoclasts. Moreover, RANKL is bound by OPG, secreted by osteoblasts, which inhibits osteoclast differentiation [4,5] (Figure 1).

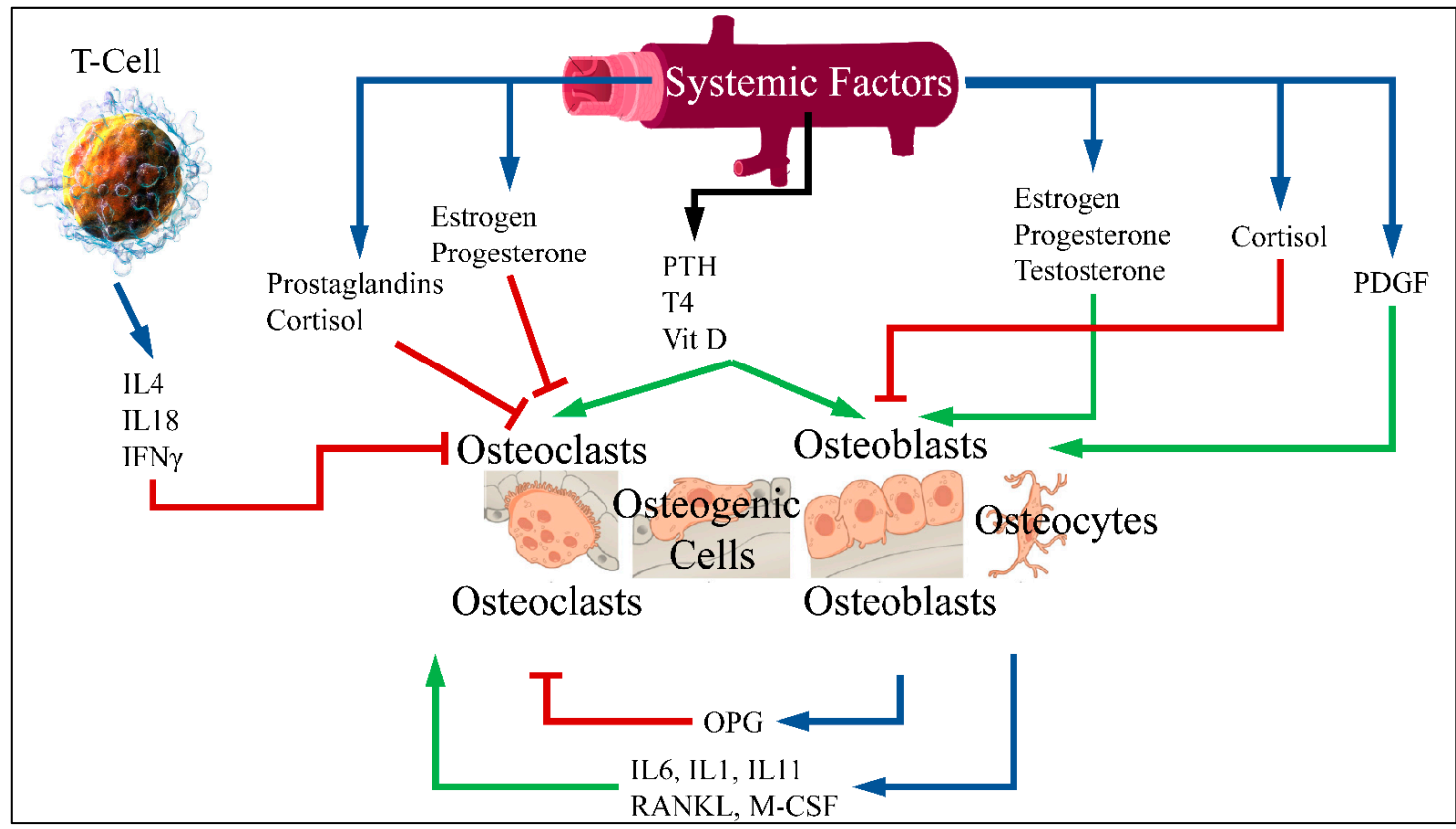

Figure 1. RANKL is an osteoclast differentiation factor. This factor binds to the RANK receptor in primary osteoclast cells and leads to differentiation and activation of osteoclasts. RANK enhances the action of osteoclast while OPG binds to RANKL and therefore inhibits bone resorption. An imbalance of OPG/RANKL/RANK expression is responsible for osteoporosis [6] (Legend: IL: Interleukins, IFN $\gamma$ : Interferon gamma, PTH: Parathormone, T4: Thyroxine, Vit D: Vitamin D, PDGF: PlateletDerived Growth Factor, OPG: Osteoprotegerin, RANKL: Receptor activator of nuclear factor kappa-B ligand, M-CSF: Macrophage colony stimulating factor. Blue arrows imply production; red arrows imply inhibition; green arrows imply stimulation) (T-Cell is reproduced under CC BY 3.0 License from https:/ / en.wikipedia.org/wiki/T_cell\#/media/File:Blausen_0625_Lymphocyte_T_cell_(crop) .png. Bone cells are reproduced under the CC BY 3.0 License from https://en.wikipedia.org/wiki/ Bone\#/media/File:604_Bone_cells.jpg. Vein is reproduced under the CC BY-SA 3.0 License from https:/ / en.wikipedia.org/wiki/Vein\#/media/File:Vein_(retouched).svg. All images last accessed on 26 September 2020).

An additional pathophysiological mechanism of GLP1 action, concerns the upregulation of RUNX2, alkaline phosphatase (ALP), collagen type-1 (COL1) and osteocalcin (OC), which are responsible for osteoblast stimulation [7]. This has been shown in a previous study on ovariectomized rats, where GLP1 agonist administration led to the upregulation of the aforementioned factors $[7,8]$. All previous studies agree on the fact that GLP1 can upregulate RUNX2, ALP, COL1 and OC as well as $N$-terminal propeptide of type I procollagen (P1NP) [9]. An additional mechanism through which GLP1 promotes bone formation is by regulating glucose metabolism. In particular, it has been found that hyperglycemia and lumbar BMD are reversely related, i.e., hyperglycemia is a factor reducing BMD. Thus, it has been speculated that GLP1 can indirectly affect bone metabolism by regulating glucose levels [10]. Another study has reported that GLP1 agonists, when binding to the GLP1 receptor (GLP1R), hydrolyze glycosylphosphatidylinositols, subsequently generating inositolphosphoglycans and therefore activating five important down-stream pathways, i.e., phosphatidylinositol-3 kinase (PI3K) and mitogen-activated protein kinase (MAPK) [11], as well as ERK1/2, p38 and JNK pathways [12]. 
Another important role of GLP1 has been found to be related to the Wnt pathway. The canonical Wnt pathway, includes LPR5/6, $\beta$-catenin, GSK-3 $\beta$ and T cell factor activation which results in osteoblast differentiation and maturation $[13,14]$. GLP1 has been found to be a direct stimulator of these pathways and factors and therefore a significant regulator of bone metabolism. Sclerostin, encoded by the SOST gene, is secreted by osteocytes and suppresses bone formation. On the other hand, GLP1 has been found to reduce SOST (sclerostin) mRNA levels, which is known to inhibit bone formation through suppression of the Wnt/nt Wnt known to inhibit bone formation through suppression of tin mRNA and COL1 [15]. On the other side of events, GLP1 has been known to regulate osteoclast functions. In particular, it has been found that GLP1 agonists are able to reduce serum levels of C-terminal cross-linked telopeptide of type I collagen (CTX-1) and urinary deoxypyridinoline (DPD)/creatinine ratio [16], thus inhibiting osteoclast action. Further on, GLP1 is able to decrease bone resorption through the calcitonin-dependent pathway [17]. The aforementioned mechanisms are summarized in Figure 2.

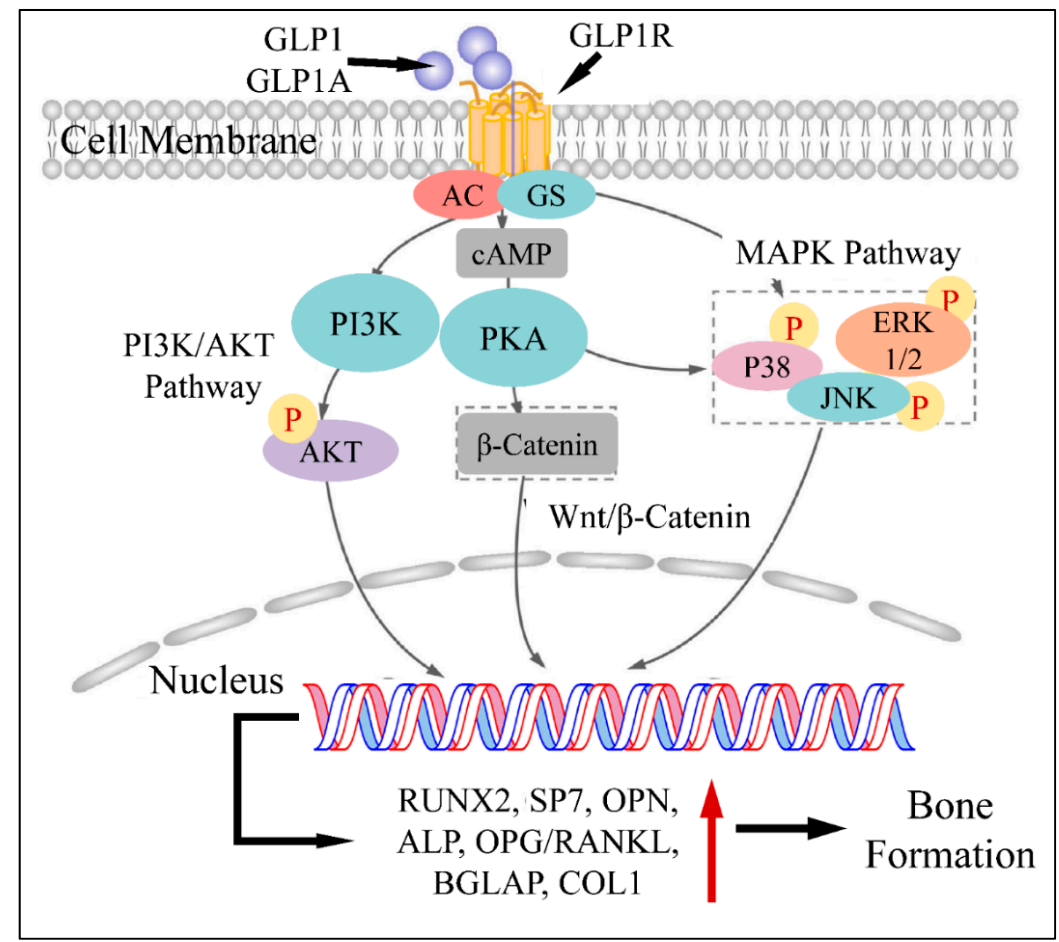

Figure 2. The mechanism of GLP1 and GLP1A in bone formation: GLP1 or GLP1A bind to GLP1R. The complex activates PI3K and PKA, which subsequently phosphorylates $(P)$ AKT, PKA as well as P38, ERK1/2 and JNK. AKT enters the nucleus and regulates gene transcription. In addition, PKA induces $\beta$-catenin, which also enters the nucleus through the Wnt/ $\beta$-catenin pathway. Similarly, phosphorylated P38, JNK and ERK1/2 enter the nucleus. All transcription factors facilitate gene expression, which leads to the induction of bone formation (Legend: GLP1: Glucagon-like peptide 1, GLP1A: Glucagon-like peptide 1 agonist, GLP1R: Glucagon-like peptide 1 receptor, GS: G-Proteins, cAMP: cyclic AMP, PI3K: Phosphoinositide 3-kinases, PKA: Protein kinase A, P38: p38 mitogenactivated protein kinase, ERK1/2: extracellular signal-regulated kinases, JNK: c-Jun $\mathrm{N}$-terminal kinase, RUNX2: Runt-related transcription factor 2, SP7: Transcription factor Sp7, OPN: Osteopontin, ALP: Alkaline phosphatase, OPG: Osteoprotegerin, BGLAP: Osteocalcin gene, COL1: Type-1 collagen. Reproduced from Xie et al. (2021) [9] under the Creative Common License CC BY 3.0 link: https: / / www.frontiersin.org/articles/10.3389/fphar.2021.697442/full, accessed on 28 January 2022).

It is apparent that GLP1 functions between a delicate balance between bone formation and bone resorption (Figure 3). Recent studies have indicated that GLP1R agonists are able to regulate the differentiation of mesenchymal stem cells to osteoblasts (reducing the differentia- 
tion of those cells to adipocytes) [18]. This has been found to take place through activation of the MAPK and PKC pathways [19], as well as the PKA/PI3K/AKT/GSK3T pathways [20].

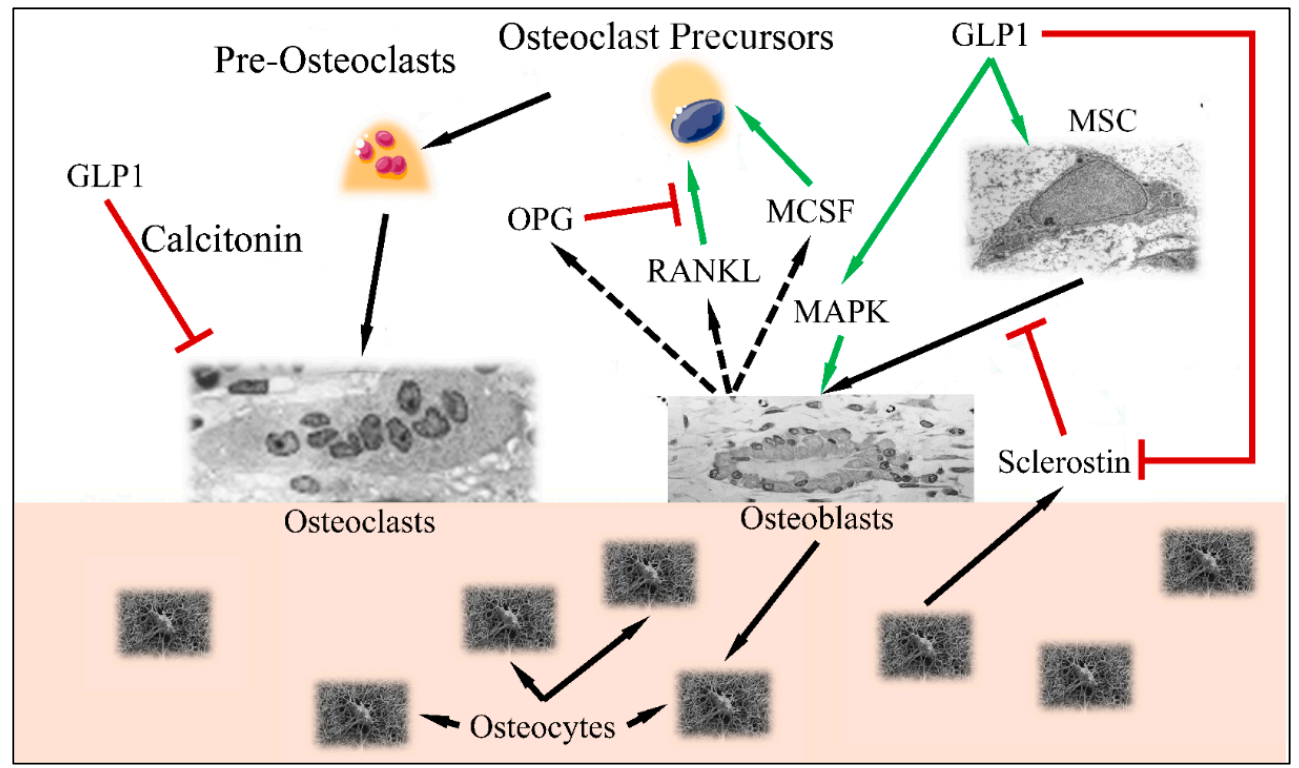

Figure 3. The balance between osteoblast and osteoclast functions: GLP1 induces MSC differentiation to osteoblasts, through the MAPK pathway. Osteocytes, produce sclerostin, which is inhibited by GLP1. Normally, stimulated osteoblasts produce MCSF, RANKL and OPG, which stimulate osteoclast precursors in order to retain bone formation balance (i.e., osteoblast and osteoclast functions remain equilibrated). GLP1 induces MAPK and osteoblast function as well as inhibits osteoclast function through the calcitonin-dependent pathway (Legend: GLP1: Glucagonlike peptide 1, MSC: Mesenchymal Stem Cells, MAPK mitogen-activated protein kinase, MCSF: macrophage colony stimulating factor, RANKL: Receptor activator of nuclear factor kappa-B ligand, OPG: Osteoprotegerin. Green arrows imply stimulation; red arrows imply inhibition; black arrows imply cellular stimulation) (Inspired and reproduced from Schiellerup et al. (2019) [21] under the Creative Common License CC BY 3.0, link: https: / / www.frontiersin.org/articles/10.3389/fendo. 2019.00075/full, accessed on 28 January 2022. MSC is reproduced under CC BY 3.0 License from https:/ / en.wikipedia.org/wiki/Mesenchymal_stem_cell, Osteoblast is reproduced under the CC BY 3.0 License from https:/ / en.wikipedia.org/wiki/Osteoblast, Osteoclast is reproduced under the CC BY-SA 3.0 License from https:/ / en.wikipedia.org/wiki/Osteoclast, Osteocytes are reproduced from https:/ / en.wikipedia.org/wiki/Osteocyte. All images last accessed on 24 January 2022).

\subsection{Diabetes and Bone Metabolism}

It has been confirmed that antidiabetic drugs, especially thiazolidinediones (TZDs) and insulin, reduce bone density and increase the risk of fracture [22,23]. TZD, also known as pioglitazone, is a synthetic peroxisome proliferator-activated receptor $\gamma(\operatorname{PPAR} \gamma)$ stimulator, and it is a potent insulin sensitizer with multiple mechanisms of action. These drugs increase glucose consumption in muscle tissues, reduce the levels of glycerol, free fatty acids and triglycerides and increase insulin sensitivity in the muscle, adipose tissue and liver. Moreover, pioglitazone inhibits hepatic gluconeogenesis, resulting in decreased endogenous glucose production [24]. The mechanisms by which basal insulin contributes to the regulation of hyperglycemia is through the reduction of hepatic glucose production and the suppression of lipolysis. According to a previous study, diabetic patients, mainly women who were treated with (TZDs) for an extended period, had an increased risk of fracture [25], which points out that deregulated insulin levels probably are related to increases in the occurrence of fractures [26].

On the other hand, incretin hormones have the ability to increase insulin secretion in response to nutrient ingestion [27]. Glucagon-like peptide-1 receptor agonists (GLP1RAs) 
stimulate insulin secretion from $\beta$ cells, reduce $\beta$ cell apoptosis, suppress glucagon secretion from $\alpha$ cells, increase liver insulin sensitivity, slow down gastric emptying and induce satiety [28]. Recently, GLP1RAs, including exenatide, liraglutide, lixisenatide, albiglutide, dulaglutide and semaglutide, are widely used for the treatment of type $2 \mathrm{di}$ abetes mellitus (T2D). These factors can be classified as short-acting (e.g., exenatide and lixisenatide, twice daily) and long-acting (e.g., albiglutide, dulaglutide, exenatide and liraglutide, once weekly), which continuously activate the GLP1 receptor (GLP1R) at recommended doses [29]. Increasing evidence has shown that GLP1RAs are beneficial for bone metabolism [30,31], while no large-scale, long-term trials are available. So far, there is only little evidence on the effects of GLP1RAs on bone density in humans. Meanwhile, in addition to decreasing blood glucose in diabetic patients, these drugs can cause relevant weight loss, which may result in a reduction of bone density. Furthermore, several studies found that these agents can promote bone formation and inhibit bone resorption, while the underlying molecular mechanisms have not been elucidated [32].

In the present study, we reviewed the literature in order to investigate the relation between GLP1 and bone metabolism. Meanwhile, we attempted to review the clinical relevance of GLP1RAs in bone metabolism.

\section{Materials and Methods}

We searched PubMed, Google Scholar and Cochrane Central Register of Controlled Trials (CENTRAL). A computerized search for the databases was accomplished by using Medical Subject Heading and entry terms such as: Glucagon-like Peptide-1 Receptor Agonists (GLP1RAs), Bone Mineral Density (BMD), Diabetes Mellitus (DM). We have included publications in English and excluded review papers and studies in the form of comments or author articles, from October 2019 to January 2020. We also included animal studies. The studies included in this systematic review were performed in Denmark, the Netherlands, China and the United States. The flowchart of the selection is presented in Figure 4.

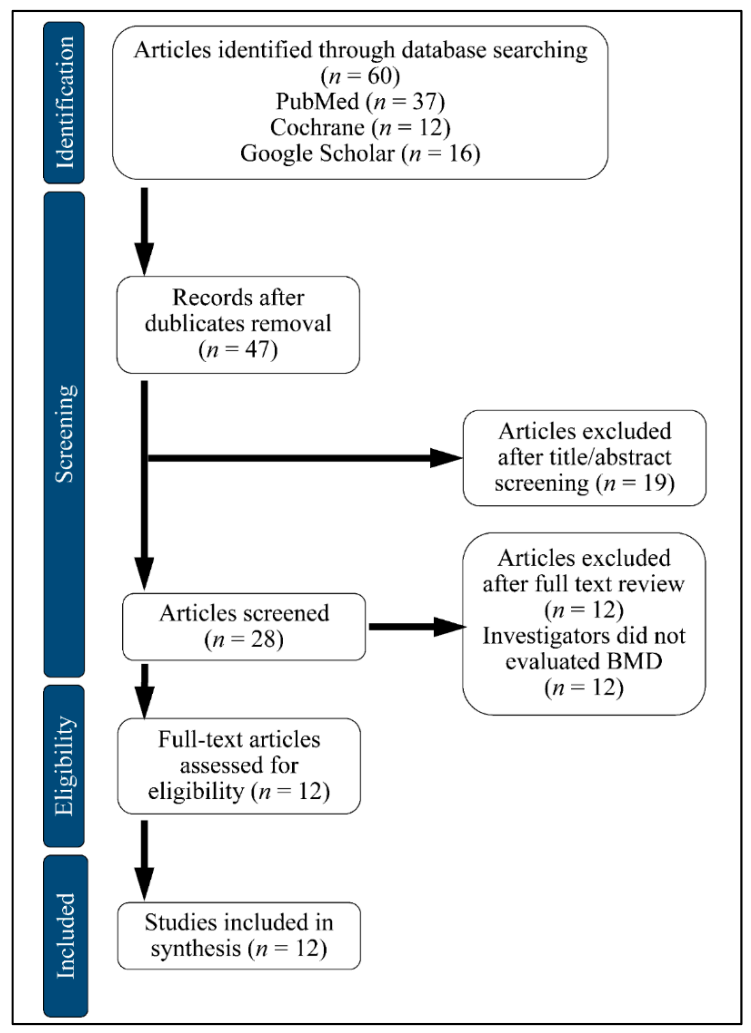

Figure 4. Flow chart of study selection.BMD: Bone Mineral Density. 


\section{Results}

There is an intense debate on whether GLP1RAs can minimize the risk of fracture [33]. Yet, they seem to be an ideal treatment option for diabetics with high-risk fractures due to the low risk of hypoglycemia [34,35]. The main findings of relevant studies are summarized in Tables 1 and 2.

Table 1. (HUMANS) Published human and animal research on the impact of GLP1 on bone metabolism.

\begin{tabular}{|c|c|c|c|c|c|c|c|c|}
\hline $\begin{array}{c}\text { Paper/ } \\
\text { Reference }\end{array}$ & Study & Subjects & $\begin{array}{l}\text { Study } \\
\text { Duration }\end{array}$ & Measurements & Fracture Risk & BMD & $\begin{array}{c}\text { Bone } \\
\text { Metabolism/ } \\
\text { Turnover } \\
\text { Markers }\end{array}$ & Main Results \\
\hline $\begin{array}{l}\text { Bunck et al. } \\
\text { (2011) [36] }\end{array}$ & RCT & $\begin{array}{l}69 \text { metformin-treated } \\
\text { T2D patients with } \\
\text { exenatide vs. } \\
\text { insulin glargine }\end{array}$ & 44 weeks & $\begin{array}{c}\text { BMD, ALP, } \\
\text { Ca, P }\end{array}$ & & $\leftrightarrow$ & $\begin{array}{c}\text { ALP: } \leftrightarrow \\
\text { Ca: } \leftrightarrow \\
\text { P: } \leftrightarrow\end{array}$ & $\begin{array}{c}\text { BMD, serum markers } \\
\text { of bone metabolism } \\
\text { and calcium } \\
\text { homeostasis } \\
\text { remained unaffected } \\
\text { by exenatide } \\
\text { treatment }\end{array}$ \\
\hline $\begin{array}{l}\text { Li et al. (2015) } \\
\text { [37] }\end{array}$ & RCT & $\begin{array}{l}62 \text { newly diagnosed } \\
\text { and drug-naïve } \\
\text { patients with T2D, } \\
\text { treated with exenatide } \\
\text { vs. insulin vs. } \\
\text { pioglitazone }\end{array}$ & 24 weeks & $\begin{array}{c}\text { HbA1C, } \\
\text { BMD, CTX, } \\
\text { OC, TRAcP5b }\end{array}$ & & $\leftrightarrow$ & $\begin{array}{l}\text { HbA1C: } \uparrow \\
\text { CTX: } \leftrightarrow \\
\text { OC: } \leftrightarrow \\
\text { TRAcP5b: } \\
\leftrightarrow \leftrightarrow\end{array}$ & $\begin{array}{l}\text { Exenatide had no } \\
\text { impact on bone } \\
\text { turnover markers or } \\
\text { BMD }\end{array}$ \\
\hline $\begin{array}{l}\text { Gilbert et al. } \\
\text { (2016) [38] }\end{array}$ & RCT & $\begin{array}{c}\text { 61 T2D patients, treated } \\
\text { with liraglutide and } \\
\text { glimepiride }\end{array}$ & $\begin{array}{c}52 \text { or } \\
104 \text { weeks }\end{array}$ & BMD & & $\leftrightarrow$ & & $\begin{array}{l}\text { Liraglutide did not } \\
\text { affect total BMD }\end{array}$ \\
\hline $\begin{array}{l}\text { Iepsen et al. } \\
(2015) \text { [39] }\end{array}$ & RCT & $\begin{array}{c}37 \text { healthy obese } \\
\text { women aged } \\
46 \pm 2 \text { years treated } \\
\text { with or without } \\
\text { liraglutide }\end{array}$ & 52 weeks & CTX-1, P1NP & & & $\begin{array}{l}\text { CTX-1: } \leftrightarrow \\
\text { P1NP: } \uparrow\end{array}$ & $\begin{array}{c}\text { Liraglutide increased } \\
\text { P1NP by } 16 \% \text { but did } \\
\text { not change CTX-1 }\end{array}$ \\
\hline $\begin{array}{c}\text { Mabilleau } \\
\text { et al. (2014) } \\
{[40]}\end{array}$ & $\begin{array}{l}\text { Meta- } \\
\text { analysis }\end{array}$ & $\begin{array}{l}\text { A meta-analysis, } \\
\text { 28 RCTs were identified } \\
\text { T2D, treated with either } \\
\text { a GLP1Ra or another } \\
\text { antidiabetic drug }\end{array}$ & $\begin{array}{l}24 \text { weeks } \\
\text { (at least) }\end{array}$ & $\begin{array}{l}\text { Incidence of } \\
\text { bone fracture }\end{array}$ & $\leftrightarrow$ & & & $\begin{array}{l}\text { GLP1RA was not } \\
\text { associated with } \\
\text { reduced fracture risk }\end{array}$ \\
\hline $\begin{array}{l}\text { Su et al. } \\
\text { (2015) [41] }\end{array}$ & $\begin{array}{l}\text { Meta- } \\
\text { analysis }\end{array}$ & $\begin{array}{l}\text { A meta-analysis, } 16 \\
\text { RCTs were identified, } \\
\text { Liraglutide or } \\
\text { exenatide treatnebt vs. } \\
\text { placebo or other } \\
\text { diabetic drugs }\end{array}$ & $\mathrm{N} / \mathrm{A}$ & $\begin{array}{l}\text { Risk of bone } \\
\text { fracture }\end{array}$ & $\begin{array}{c}\text { Liraglutide: } \downarrow \\
\text { Exenatide: } \uparrow\end{array}$ & & & $\begin{array}{l}\text { Liraglutide might } \\
\text { reduce the risk of } \\
\text { bone fractures while } \\
\text { exenatide might } \\
\text { increase the risk of } \\
\text { bone fractures }\end{array}$ \\
\hline $\begin{array}{l}\text { Zhang et al. } \\
\text { (2018) [42] }\end{array}$ & $\begin{array}{l}\text { Meta- } \\
\text { analysis }\end{array}$ & $\begin{array}{l}\text { Network meta-analysis, } \\
54 \text { RCTs were } \\
\text { identified, } \\
\text { GLP1Ra vs. other } \\
\text { hypoglycemic drugs vs. } \\
\text { placebo }\end{array}$ & $\mathrm{N} / \mathrm{A}$ & Fracture risk & Exenatide: $\downarrow$ & & & $\begin{array}{l}\text { Exenatide was } \\
\text { associated with a } \\
\text { decreased risk of } \\
\text { bone fracture }\end{array}$ \\
\hline $\begin{array}{l}\text { Driessen et al. } \\
\text { (2015) [43] }\end{array}$ & $\begin{array}{l}\text { Case } \\
\text { Control }\end{array}$ & $\begin{array}{l}\text { A case-control study of } \\
\text { NIAD users vs. } \\
\text { GLP1RA users }\end{array}$ & $\mathrm{N} / \mathrm{A}$ & $\begin{array}{l}\text { Risk of } \\
\text { fractures }\end{array}$ & $\leftrightarrow$ & & & $\begin{array}{l}\text { GLP1RA was not } \\
\text { associated with } \\
\text { fracture risk }\end{array}$ \\
\hline $\begin{array}{l}\text { Driessen et al. } \\
\text { (2015) [44] }\end{array}$ & $\begin{array}{l}\text { Case } \\
\text { Control }\end{array}$ & $\begin{array}{l}\text { Population-based } \\
\text { cohort, T2D patients } \\
\text { with at least one } \\
\text { prescription for NIAD } \\
\text { GLP1RA vs. } \\
\text { non-GLP1RA }\end{array}$ & $\mathrm{N} / \mathrm{A}$ & $\begin{array}{l}\text { Bone fracture } \\
\text { risk }\end{array}$ & $\leftrightarrow$ & & & $\begin{array}{l}\text { GLP1RA was not } \\
\text { associated with } \\
\text { decreased bone } \\
\text { fracture }\end{array}$ \\
\hline
\end{tabular}

Abbreviations: $\uparrow$ increase; $\downarrow$ decrease; $\leftrightarrow$ neutral; BMD, bone mineral density; ALP, Alkaline Phosphatase; CTX, Cterminal Telopeptide; OC: Osteocalcin; TRAcP5b, Tartrate-resistant acid phosphatase 5b; CTX-1, carboxy-terminal cross-linked telopeptide of type 1 collagen; P1NP, procollagen-1 N-terminal peptide; GLP1RA, glucagon-like peptide-1 receptor agonists; T2D, type 2 diabetes mellitus; RCTs, randomized control trials; NIAD, non-insulin antidiabetic drug; HbA1C, glycosylated hemoglobin; N/A, Not Available. 
Table 2. (ANIMALS) Published human and animal research on the impact of GLP1 on bone metabolism.

\begin{tabular}{|c|c|c|c|c|c|}
\hline Paper/Reference & Subjects & Measurements & BMD & $\begin{array}{c}\text { Bone } \\
\text { Metabolism/Turnover } \\
\text { Markers }\end{array}$ & Main Results \\
\hline Ma et al. (2013) [16] & $\begin{array}{l}\text { Old ovariectomy } \\
\text { rats }\end{array}$ & $\begin{array}{c}\text { DPD/creatinine, } \\
\text { CTX-1, ALP, OC, } \\
\text { P1NP, Coll-1, Runx2, } \\
\text { OPG/RANKL }\end{array}$ & & $\begin{array}{c}\text { DPD/creatinine: } \downarrow \\
\text { CTX-1: } \downarrow \\
\text { ALP: } \uparrow, \text { OC: } \uparrow, \\
\text { P1NP: } \uparrow, \text { Coll-1: } \uparrow \\
\text { Runx2: } \uparrow \\
\text { OPG/RANKL: } \uparrow\end{array}$ & $\begin{array}{c}\text { Exendin-4 } \\
\text { prevented } \\
\text { osteopenia by } \\
\text { increasing bone } \\
\text { formation markers } \\
\text { and decreasing } \\
\text { bone resorption } \\
\text { markers }\end{array}$ \\
\hline $\begin{array}{c}\text { Nuche-Berenguer } \\
\text { (2009) [8] }\end{array}$ & $\begin{array}{c}\text { T2D rats, } \\
\text { insulin-resistant } \\
\text { rats vs. normal rats }\end{array}$ & $\begin{array}{c}\text { BMD } \\
\text { OC, OPG/RANKL }\end{array}$ & $\uparrow$ & $\begin{array}{c}\text { OC: } \uparrow, \\
\text { OPG/RANKL: } \uparrow \\
\text { (T2D+IR) }\end{array}$ & $\begin{array}{l}\text { GLP1 increased } \\
\text { bone formation }\end{array}$ \\
\hline $\begin{array}{l}\text { Nuche-Berenguer } \\
\text { (2010) [11] }\end{array}$ & $\begin{array}{c}\text { T2D rats, } \\
\text { insulin-resistant } \\
\text { rats vs. normal rats }\end{array}$ & $\begin{array}{c}\text { BMD, } \\
\text { OPG/RANKL, } \\
\text { TRAP5b, OC }\end{array}$ & $\uparrow$ & $\begin{array}{c}\text { OPG/RANKL: } \uparrow \\
\text { (T2D+IR) } \\
\text { TRAP5b: } \downarrow \\
\text { OC: } \uparrow\end{array}$ & $\begin{array}{l}\text { Exendin- } 4 \text { exerted } \\
\text { osteogenic effects }\end{array}$ \\
\hline $\begin{array}{l}\text { Nuche-Berenguer } \\
\text { (2011) [45] }\end{array}$ & $\begin{array}{l}\text { Hyperlipidic and } \\
\text { hypercaloric rats }\end{array}$ & $\begin{array}{l}\text { OPG/RANKL } \\
\text { OC }\end{array}$ & & $\begin{array}{c}\text { RANKL/OPG: } \uparrow \\
\text { OC: } \uparrow\end{array}$ & $\begin{array}{c}\text { GLP1 and } \\
\text { Exendin-4 reversed } \\
\text { bone alterations in } \\
\text { hyperlipidic rats }\end{array}$ \\
\hline $\begin{array}{c}\text { Yamada et al. (2017) } \\
\text { [17] }\end{array}$ & $\begin{array}{l}\text { GLP1R knockout } \\
\text { mice vs. wild-type } \\
\text { mice }\end{array}$ & Calcitonin, DPD & & DPD: $\downarrow$ & $\begin{array}{l}\text { GLP1 inhibited } \\
\text { bone resorption in a } \\
\text { calcitonin } \\
\text { dependent way }\end{array}$ \\
\hline $\begin{array}{c}\text { Kim et al. (2013) } \\
{[46]}\end{array}$ & $\begin{array}{l}\text { 4-week-old male } \\
\text { T2D OLEFT rats } \\
\text { with saline vs. } \\
\text { OLEFT rats with } \\
\text { exendin-4 vs. LETO } \\
\text { control rats with } \\
\text { saline }\end{array}$ & $\begin{array}{c}\text { mRNA expression } \\
\text { SOST/sclerostin } \\
\text { Sclerostin } \\
\text { OC } \\
\text { TRAP5D } \\
\text { BMD }\end{array}$ & $\uparrow$ & $\begin{array}{c}\text { mRNA expression: } \downarrow \\
\text { SOST/sclerostin: } \downarrow \\
\text { Sclerostin: } \downarrow \\
\text { OC: } \uparrow \\
\text { TRAP5D: } \leftrightarrow\end{array}$ & $\begin{array}{l}\text { Exendin- } 4 \text { might } \\
\text { raise } \mathrm{BMD} \text { by } \\
\text { reducing the } \\
\text { expression of } \\
\text { SOST/sclerostin in } \\
\text { osteocytes }\end{array}$ \\
\hline Sun et al. (2015) [20] & $\begin{array}{l}\text { 5-month-old female } \\
\text { nondiabetic and } \\
\text { OVX wistar rats, } \\
\text { Sham+vehicle vs. } \\
\text { OVX+vehicle vs. } \\
\text { OVX+exendin-4 }\end{array}$ & $\begin{array}{c}\text { BMD } \\
\text { Runx2 } \\
\text { ALP } \\
\text { Coll-1 } \\
\text { PPAR } \gamma \\
\text { C } / \text { EBP } \alpha \\
\text { P38 } \\
\text { P42/44 } \\
\text { B-catenin proteins }\end{array}$ & $\uparrow$ & $\begin{array}{c}\text { Runx2: } \uparrow \\
\text { ALP: } \uparrow \\
\text { Coll-1: } \uparrow \\
\text { PPAR } \gamma: \downarrow \\
\text { C/EBP } \alpha: \downarrow \\
\text { P38: } \uparrow \\
\text { P42/44: } \uparrow \\
\text { B-catenin proteins: } \uparrow\end{array}$ & $\begin{array}{l}\text { Exendin- } 4 \text { exerted } \\
\text { bone-preserving } \\
\text { effects in OVX rats }\end{array}$ \\
\hline
\end{tabular}

Abbreviations: $\uparrow$ increase; $\downarrow$ decrease; $\leftrightarrow$ neutral; BMD, bone mineral density; T2D, type 2 diabetes mellitus CTX-1, C-telopeptide of type I collagen; ALP, alkaline phosphatase; OC, osteocalcin; OPG/RANKL, osteoprotegerin/receptor activator of nuclear factor- $\mathrm{kB}$ ligand; GLP1R, glucagon-like peptide-1 receptor; DPD, deoxypyridinoline; OLETF rats, Otsuka Long-Evans Tokushima Fatty rats; LETO rats, Long-Evans Tokushima Otsuka (LETO) rat; OVX, ovariectomized; TRAcP5b, tartrate-resistant alkaline phosphatase 5b; Runx2, runt-related transcription factor 2; Coll-1, collagen 1; PTH, parathyroid hormone; $\mathrm{PPAR} \gamma$, peroxisome proliferator-activated receptor $\gamma$.

\subsection{Human Studies}

For the studies included in this systematic review, the sample size ranged from 61 to 69 , the mean age of type 2 diabetes mellitus (T2D) was 54 years and the study duration varied from 24 weeks to 2 years.

The study population was consistent, but heterogeneity in doses and duration of therapy was observed. Specifically, in Bunck et al. (2011) [36], metformin-treated patients were included, who were randomized to receive exenatide twice daily; in Li et al. (2015) [37], patients newly diagnosed with T2D assigned to exenatide treatment at a dose of $5 \mu \mathrm{g}$ twice daily were enrolled; in Gilbert et al. (2016) [38], patients receiving liraglutide treatment $1.8 \mathrm{mg} /$ day and liraglutide $1.2 \mathrm{mg} /$ day were examined; while in Iepsen et al. (2015) [39], 37 healthy obese women who were treated with liraglutide $1.2 \mathrm{mg} /$ day were included. All the four randomized controlled trials (RCTs) consisted of an intervention group and a control group. Generally, the effect of liraglutide and exenatide was investigated in the clinical trials (Table 1). 
According to the study by Bunck et al. (2011), BMD was not affected by exenatide, significant weight loss was observed in the group of T2D, while alkaline phosphatase (ALP), calcium $\left(\mathrm{Ca}^{+2}\right)$ and phosphate $\left(\mathrm{P}^{+4}\right)$, as the markers of bone metabolism and calcium homeostasis, remained unaffected after a 44-week treatment [36]. Similarly, in a two-center, randomized, parallel-group clinical trial, the effects of exenatide on BMD and bone turnover markers including osteocalcin (OC), C-telopeptide of type I collagen (CTX-1) and tartrateresistant alkaline phosphatase $5 b$ (TRAcP5b) were compared with insulin or pioglitazone treatment ( $n=62$, newly diagnosed T2D patients). In the study, no improvement in BMD or bone turnover markers was detected, despite the amelioration of glucose levels, after 24 weeks of treatment [37] (Table 1).

In Gilbert et al. (2016), a multicenter trial examined the effectiveness of liraglutide (1.2 and $1.8 \mathrm{mg}$ /day) versus glimepiride monotherapy in T2D. After 52 and 104 weeks of treatment, there was no apparent difference in mean total BMD in the diabetic patients [38]. However, Iepsen et al. (2015) demonstrated that liraglutide increased bone formation marker $N$-terminal propeptide of type1procollagen (P1NP) by $16 \%$ in a group of healthy obese women, while the bone resorption marker CTX-1 was not affected [39] (Table 1).

With respect to fracture risk, Mabilleau et al. (2014) revealed, in a meta-analysis of 28 RCTs, that GLP1RA had no impact on the risk of bone fracture in T2D, as compared to the patients treated with other antidiabetic drugs [40]. This was followed by a metaanalysis conducted by Su et al. (2015), where 16 RCTs were included in order to investigate the risk of bone fractures associated with liraglutide or exenatide, compared to placebo or other active drugs. Data revealed that liraglutide was associated with a decreased risk of fracture, while exenatide treatment was remarkably associated with an increased risk of fracture [41]. On the other hand, Zhang et al. (2018) conducted a network metaanalysis based on 54 RCTs where 28,353 out of 49,602 participants were treated with exenatide, liraglutide, semaglutide, dulaglutide, albiglutide or lixisenatide, while the others were treated with other antidiabetic drugs or placebo. It was found that exenatide was remarkably associated with a lower risk of fracture, as compared to placebo. Exenatide is the best option concerning the risk of fracture, followed by dulaglutide, liraglutide, albiglutide, lixisenatide and semaglutide [42]. No association was found between GLP1RAs and fracture risks in both studies conducted by Driessen et al. (2015) [43,44] (Table 1).

The difference in doses and duration of therapy with GLP1RAs and the difference in the number of trials included in meta-analyses may have led to the above-mentioned conflicting findings [27]. Further studies are needed to elucidate the effect of different GLP1RAs on bone formation [47].

\subsection{Animal Studies}

In opposition to what has been recognized in humans, animal models of T2D are associated with increased bone formation and decreased bone resorption. In ovariectomyinduced (OVX) osteoporosis, old rats receiving exendin- 4 at a dose of 3 or $10 \mu \mathrm{g} / \mathrm{kg} / \mathrm{day}$ for 16 weeks were associated with increased serum ALP levels, which is a significant biomarker of bone formation, and inhibited bone resorption. Such changes might be induced by increasing OPG/RANKL ratio. On the contrary, serum CTX-1, a major biomarker for the estimation of bone resorption rate, was decreased by exendin-4 [16] (Table 2).

In the study conducted by Nuche-Berenguer et al. (2009), several bone characteristics in T2D and insulin resistant (IR) rat models were evaluated. They investigated the effect of GLP1 treatment on T2D and IR rats, and found that following GLP1 treatment, the OPG/RANKL ratio was increased in T2D and IR rats as compared to normal rats. These findings indicated that GLP1 could be a salutary therapeutic factor for increasing bone formation [8]. It has also been mentioned that exendin-4 administration in T2D and IR rats promoted bone formation via the Wnt signaling pathway [11]. In another study by Nuche-Berenguer et al. (2011) based on a hyperlipidic model, exedin- 4 also induced a significant increase in the tibias' OPG/RANKL ratio and osteocalcin, as compared to the control [45] (Table 2). 
GLP1 receptor is expressed in thyroid C cells and induces calcitonin secretion. GLP1R ${ }^{-/-}$ mice had an increased level of urinary deoxypyridinoline (DPD), which was associated with increased bone resorption. When treating these $\mathrm{GLP}_{1} \mathrm{R}^{-/-}$mice with calcitonin, moderation of the increased urinary DPD was observed. As a consequence, it can be deduced that GLP1 inhibits bone resorption in a calcitonin dependent way [17]. Additionally, it has been noticed that exendin-4 decreased the mRNA and protein levels of SOST-sclerostin in osteocyte-like MLO-Y4 cells, and also reduced the serum sclerostin level in T2D OLEFT rats. On the other hand, the serum levels of osteocalcin and femoral BMD were increased by exendin- 4 . Exendin-4 might raise BMD by reducing the expression of SOST/sclerostin in osteocytes in T2D [46]. Meanwhile, GLP1 may also guide cell differentiation via regulating the MAPK and Wnt signaling pathways to promote RunX2 activity. Moreover, GLP-1RAs have been demonstrated to possess anabolic effects on bones in ovariectomized animal models without diabetes, whereas exenatide is associated with bone mass elevation in both trabecular and cortical bones [20].

\section{Discussion}

The present systematic review investigated the effect of GLP1RAs on BMD as well as attempted to find the clinical relevance of GLP1RAs treatment in bone metabolism. Previous studies have shown that patients with diabetes mellitus are associated with an increased risk of bone fractures [48]. It is well-known that diabetes causes chronic complications such as neuropathy and retinopathy, while bone fractures are recognized as a significant diabetes complication with high mortality and morbidity [49]. The connection between diabetes and the frequency of fractures as well as the underlying mechanisms have not been clarified. It has been confirmed that anti-hyperglycemic remedies, especially TZDs and insulin, known for maintaining glycemic levels, can affect bone metabolism by reducing bone density and increasing the risk of fracture [48]. GLP1RAs are widely used for the treatment of T2D and seem to be an ideal treatment therapy option for diabetes patients with high-risk fractures due to the low risk of hypoglycemia [50]. The pleiotropic effect of GLP1RAs has facilitated clinicians investigating their relationship to bone metabolism.

Although, some human studies have reported that GLP1RAs have no impact on BMD or the turnover markers, all agree on the fact that administration of GLP1A can be beneficial for bone metabolism. On the other hand, several clinical trials showed that GLP1RAs and other antidiabetic drugs were found to be associated with either increased or decreased risks of fracture. A very recent report, indicated that the use of exenatide and dulaglutide in T2D patients, did not have any effect on BMD after 52 weeks of treatment, while the same cohort manifested a significant improvement of BMD when treated with insulin glargine [51]. In general, all available studies agree on one point; that the use of GLP1 agonists in the treatment of diabetes is beneficial for both the disease in questions as well as bone metabolism [52]. Similarly, a recent report suggested that GLP1 agonists when administered to T2D patients with concurrent cardiovascular disease, lead to significant reduction of hospitalizations, as well as kept bone metabolism unaffected [53]. In addition, a recent interesting review on the subject indicated that the administration of GLP1 agonists had an effect on the suppression of chronic inflammation by reducing the levels of inflammatory cytokines [54]. The same work indicated that GLP1 agonists lead to a significant increase in femoral and vertebral bone mass, confirming previous findings on the role of GLP1 agonists.

The aforementioned clinical studies and meta-analyses had some limitations. First of all, the number of control groups in many studies was too small to draw firm conclusions. Therefore, the effects of GLP1RAs on BMD and on fracture risk would have been adequately demonstrated if the size of the study population was larger. Second, the follow-up duration in many trials was insufficient to strongly support the association between GLP1RA treatments and bone fractures. It is also noteworthy that the age of the populations under investigation was younger than the typical age of the osteoporosis population. Furthermore, there was no distinction between men and women in the samples' cohorts. Therefore, the protective effect of GLP1RAs on bone fracture risk was potentially undermined by these 
factors (i.e., age and gender). In addition, bone fracture was not the primary endpoint in the included meta-analyses, leading to insufficient registration and recording.

On the other hand, most animal studies have shown an increase in BMD and bone turnover markers, which was in contrast to that observed in human studies. In rodent models, administration of GLP1 or its analogue exendin- 4 for 3 days increased BMD and augmented the expression of osteoblast markers through diverse mechanisms, such as interacting with the Wnt pathway or increasing the OPG/RANKL ratio in normal, diabetic and hyperlipidic rats $[8,11,45]$. In addition, it has been indicated that GLP1R may inhibit bone formation through a calcitonin dependent pathway in thyroid $\mathrm{C}$ cells by stimulating calcitonin releasing [17]. Another mechanism through which exendin-4 increases BMD is reducing the expression of SOST/sclerostin in MLO-Y4 cells, which leads to increased serum levels of osteocalcin, decreased serum levels of sclerostin and increased femoral BMD in T2D rats [46].

In fact, differences in the expression levels of GLP1 might be attributable to the inconsistent results between animal studies and clinical trials [16]. Another explanation for the discrepancy between human and animal studies might reside in the use of much higher drug doses in the experimental models, which provided a more favorable effect than those administered in the human population. In addition, the duration of treatment in clinical trials was not sufficiently long to examine the anabolic, anti-resorptive and protective effects of GLP1RAs on bone and fracture risk. Furthermore, not all human studies contained information about bone status or measured the serum markers of bone formation and resorption at baseline, and thus the possible action of GLP1RAs was not highlighted [30].

The limitations arising from the present systematic review included the lack of sample's homogeneity (both human and animal populations), a small number of registered participants and short duration of follow-up treatment. Another limitation of the present review is the methodological heterogeneity as different GLP1RAs were examined, which have different pharmacokinetic profiles.

\section{Conclusions}

Patients suffering from DM are at high risk of bone fracture. This systematic review concluded that antidiabetic medication could intervene with skeletal physiology. GLP1RAs belong to the incretin family of antidiabetic drugs. In addition to their known glucoseindependent lowering action, it has been reported that these agents are associated with beneficial skeletal effects. Overall clinical data indicated that GLP1RAs have a neutral impact on bone health and do not affect the rates of fracture. However, further double-blind RCTs are required to draw more meaningful and significant conclusions on their efficacy on BMD.

Author Contributions: Conceptualization, I.D. and A.N.T.; methodology, I.D., G.I.L. and A.N.T.; investigation, A.N., E.D., G.F., O.G. and A.K.; resources, A.N.T. and G.I.L.; data curation, I.D., A.N., E.D., G.F., O.G. and A.K.; writing—original draft preparation, I.D., E.V. and A.N.T.; writing—review and editing, I.D., E.V., G.I.L. and A.N.T.; visualization, A.N.T. and G.I.L.; supervision, A.N.T.; project administration, A.N.T. and E.V.; funding acquisition, A.N.T. and G.I.L. All authors have read and agreed to the published version of the manuscript.

Funding: This research received no external funding.

Institutional Review Board Statement: Not applicable.

Informed Consent Statement: Not applicable.

Data Availability Statement: Not applicable.

Conflicts of Interest: The authors declare no conflict of interest. 


\section{References}

1. Janghorbani, M.; Van Dam, R.M.; Willett, W.C.; Hu, F.B. Systematic review of type 1 and type 2 diabetes mellitus and risk of fracture. Am. J. Epidemiol. 2007, 166, 495-505. [CrossRef] [PubMed]

2. Montagnani, A.; Gonnelli, S. Antidiabetic therapy effects on bone metabolism and fracture risk. Diabetes Obes. Metab. 2013, 15, 784-791. [CrossRef] [PubMed]

3. Office of the Surgeon General (US). Bone Health and Osteoporosis: A Report of the Surgeon General; Department of Health and Human Services: Rockville, MD, USA, 2004.

4. Luo, G.; Liu, H.; Lu, H. Glucagon-like peptide-1(glp-1) receptor agonists: Potential to reduce fracture risk in diabetic patients? Br. J. Clin. Pharmacol. 2016, 81, 78-88. [CrossRef] [PubMed]

5. Hadjidakis, D.J.; Androulakis, I.I. Bone remodeling. Ann. N. Y. Acad. Sci. 2006, 1092, 385-396. [CrossRef] [PubMed]

6. Tsartsalis, A.N.; Dokos, C.; Kaiafa, G.D.; Tsartsalis, D.N.; Kattamis, A.; Hatzitolios, A.I.; Savopoulos, C.G. Statins, bone formation and osteoporosis: Hope or hype? Hormones 2012, 11, 126-139. [CrossRef] [PubMed]

7. Yoshimura, N.; Muraki, S.; Oka, H.; Kawaguchi, H.; Nakamura, K.; Akune, T. Biochemical markers of bone turnover as predictors of osteoporosis and osteoporotic fractures in men and women: 10-year follow-up of the taiji cohort. Mod. Rheumatol. 2011, 21, 608-620. [CrossRef] [PubMed]

8. Nuche-Berenguer, B.; Moreno, P.; Esbrit, P.; Dapia, S.; Caeiro, J.R.; Cancelas, J.; Haro-Mora, J.J.; Villanueva-Penacarrillo, M.L. Effect of glp-1 treatment on bone turnover in normal, type 2 diabetic, and insulin-resistant states. Calcif. Tissue Int. 2009, 84, 453-461. [CrossRef]

9. Xie, B.; Chen, S.; Xu, Y.; Han, W.; Hu, R.; Chen, M.; Zhang, Y.; Ding, S. The impact of glucagon-like peptide 1 receptor agonists on bone metabolism and its possible mechanisms in osteoporosis treatment. Front. Pharmacol. 2021, 12, 697442. [CrossRef]

10. Terzi, R.; Dindar, S.; Terzi, H.; Demirtas, O. Relationships among the metabolic syndrome, bone mineral density, bone turnover markers, and hyperglycemia. Metab. Syndr. Relat. Disord. 2015, 13, 78-83. [CrossRef]

11. Nuche-Berenguer, B.; Moreno, P.; Portal-Nunez, S.; Dapia, S.; Esbrit, P.; Villanueva-Penacarrillo, M.L. Exendin-4 exerts osteogenic actions in insulin-resistant and type 2 diabetic states. Regul. Pept. 2010, 159, 61-66. [CrossRef]

12. Feng, Y.; Su, L.; Zhong, X.; Guohong, W.; Xiao, H.; Li, Y.; Xiu, L. Exendin-4 promotes proliferation and differentiation of mc3t3-e1 osteoblasts by mapks activation. J. Mol. Endocrinol. 2016, 56, 189-199. [CrossRef] [PubMed]

13. Etheridge, S.L.; Spencer, G.J.; Heath, D.J.; Genever, P.G. Expression profiling and functional analysis of wnt signaling mechanisms in mesenchymal stem cells. Stem Cells 2004, 22, 849-860. [CrossRef] [PubMed]

14. Shi, Y.C.; Worton, L.; Esteban, L.; Baldock, P.; Fong, C.; Eisman, J.A.; Gardiner, E.M. Effects of continuous activation of vitamin d and wnt response pathways on osteoblastic proliferation and differentiation. Bone 2007, 41, 87-96. [CrossRef] [PubMed]

15. Winkler, D.G.; Sutherland, M.K.; Geoghegan, J.C.; Yu, C.; Hayes, T.; Skonier, J.E.; Shpektor, D.; Jonas, M.; Kovacevich, B.R.; Staehling-Hampton, K.; et al. Osteocyte control of bone formation via sclerostin, a novel bmp antagonist. EMBO J. 2003, 22, 6267-6276. [CrossRef] [PubMed]

16. Ma, X.; Meng, J.; Jia, M.; Bi, L.; Zhou, Y.; Wang, Y.; Hu, J.; He, G.; Luo, X. Exendin-4, a glucagon-like peptide-1 receptor agonist, prevents osteopenia by promoting bone formation and suppressing bone resorption in aged ovariectomized rats. J. Bone Miner. Res. Off. J. Am. Soc. Bone Miner. Res. 2013, 28, 1641-1652. [CrossRef] [PubMed]

17. Yamada, C.; Yamada, Y.; Tsukiyama, K.; Yamada, K.; Udagawa, N.; Takahashi, N.; Tanaka, K.; Drucker, D.J.; Seino, Y.; Inagaki, $\mathrm{N}$. The murine glucagon-like peptide-1 receptor is essential for control of bone resorption. Endocrinology 2008, 149, 574-579. [CrossRef] [PubMed]

18. Jiang, Y.; Jahagirdar, B.N.; Reinhardt, R.L.; Schwartz, R.E.; Keene, C.D.; Ortiz-Gonzalez, X.R.; Reyes, M.; Lenvik, T.; Lund, T.; Blackstad, M.; et al. Pluripotency of mesenchymal stem cells derived from adult marrow. Nature 2002, 418, 41-49. [CrossRef]

19. Sanz, C.; Vazquez, P.; Blazquez, C.; Barrio, P.A.; Mdel, M.A.; Blazquez, E. Signaling and biological effects of glucagon-like peptide 1 on the differentiation of mesenchymal stem cells from human bone marrow. Am. J. Physiol. Endocrinol. Metab. 2010, 298, E634-E643. [CrossRef]

20. Sun, H.X.; Lu, N.; Liu, D.M.; Zhao, L.; Sun, L.H.; Zhao, H.Y.; Liu, J.M.; Tao, B. The bone-preserving effects of exendin-4 in ovariectomized rats. Endocrine 2016, 51, 323-332. [CrossRef]

21. Schiellerup, S.P.; Skov-Jeppesen, K.; Windelov, J.A.; Svane, M.S.; Holst, J.J.; Hartmann, B.; Rosenkilde, M.M. Gut hormones and their effect on bone metabolism. Potential drug therapies in future osteoporosis treatment. Front. Endocrinol. 2019, 10, 75. [CrossRef]

22. Mosenzon, O.; Wei, C.; Davidson, J.; Scirica, B.M.; Yanuv, I.; Rozenberg, A.; Hirshberg, B.; Cahn, A.; Stahre, C.; Strojek, K.; et al. Incidence of fractures in patients with type 2 diabetes in the savor-timi 53 trial. Diabetes Care 2015, 38, 2142-2150. [CrossRef] [PubMed]

23. Adil, M.; Khan, R.A.; Kalam, A.; Venkata, S.K.; Kandhare, A.D.; Ghosh, P.; Sharma, M. Effect of anti-diabetic drugs on bone metabolism: Evidence from preclinical and clinical studies. Pharmacol. Rep. PR 2017, 69, 1328-1340. [CrossRef] [PubMed]

24. McDonough, A.K.; Rosenthal, R.S.; Cao, X.; Saag, K.G. The effect of thiazolidinediones on bmd and osteoporosis. Nat. Clin. Pract. Endocrinol. Metab. 2008, 4, 507-513. [CrossRef] [PubMed]

25. Chen, H.H.; Horng, M.H.; Yeh, S.Y.; Lin, I.C.; Yeh, C.J.; Muo, C.H.; Sung, F.C.; Kao, C.H. Glycemic control with thiazolidinedione is associated with fracture of t2dm patients. PLoS ONE 2015, 10, e0135530. [CrossRef] [PubMed]

26. Antonopoulou, M.; Bahtiyar, G.; Banerji, M.A.; Sacerdote, A.S. Diabetes and bone health. Maturitas 2013, 76, 253-259. [CrossRef] 
27. Kalaitzoglou, E.; Fowlkes, J.L.; Popescu, I.; Thrailkill, K.M. Diabetes pharmacotherapy and effects on the musculoskeletal system. Diabetes/Metab. Res. Rev. 2019, 35, e3100. [CrossRef]

28. Zhao, C.; Liang, J.; Yang, Y.; Yu, M.; Qu, X. The impact of glucagon-like peptide-1 on bone metabolism and its possible mechanisms Front. Endocrinol. 2017, 8, 98. [CrossRef]

29. Gentilella, R.; Pechtner, V.; Corcos, A.; Consoli, A. Glucagon-like peptide-1 receptor agonists in type 2 diabetes treatment: Are they all the same? Diabetes/Metab. Res. Rev. 2019, 35, e3070. [CrossRef]

30. Mabilleau, G.; Pereira, M.; Chenu, C. Novel skeletal effects of glucagon-like peptide-1 (glp-1) receptor agonists. J. Endocrinol. 2018, 236, R29-R42. [CrossRef]

31. Ceccarelli, E.; Guarino, E.G.; Merlotti, D.; Patti, A.; Gennari, L.; Nuti, R.; Dotta, F. Beyond glycemic control in diabetes mellitus: Effects of incretin-based therapies on bone metabolism. Front. Endocrinol. 2013, 4, 73. [CrossRef]

32. Mannucci, E.; Dicembrini, I. Drugs for type 2 diabetes: Role in the regulation of bone metabolism. Clin. Cases Miner. Bone Metab. Off. J. Ital. Soc. Osteoporos. Miner. Metab. Skelet. Dis. 2015, 12, 130-134. [CrossRef] [PubMed]

33. Mohsin, S.; Baniyas, M.M.; AlDarmaki, R.S.; Tekes, K.; Kalasz, H.; Adeghate, E.A. An update on therapies for the treatment of diabetes-induced osteoporosis. Expert Opin. Biol. Ther. 2019, 19, 937-948. [CrossRef] [PubMed]

34. Meier, C.; Schwartz, A.V.; Egger, A.; Lecka-Czernik, B. Effects of diabetes drugs on the skeleton. Bone 2016, 82, 93-100. [CrossRef] [PubMed]

35. Onoviran, O.F.; Li, D.; Smith, S.T.; Raji, M.A. Effects of glucagon-like peptide 1 receptor agonists on comorbidities in older patients with diabetes mellitus. Ther. Adv. Chronic Dis. 2019, 10, 2040622319862691. [CrossRef] [PubMed]

36. Bunck, M.C.; Eliasson, B.; Corner, A.; Heine, R.J.; Shaginian, R.M.; Taskinen, M.R.; Yki-Jarvinen, H.; Smith, U.; Diamant, M Exenatide treatment did not affect bone mineral density despite body weight reduction in patients with type 2 diabetes. Diabetes Obes. Metab. 2011, 13, 374-377. [CrossRef] [PubMed]

37. Li, R.; Xu, W.; Luo, S.; Xu, H.; Tong, G.; Zeng, L.; Zhu, D.; Weng, J. Effect of exenatide, insulin and pioglitazone on bone metabolism in patients with newly diagnosed type 2 diabetes. Acta Diabetol. 2015, 52, 1083-1091. [CrossRef] [PubMed]

38. Gilbert, M.P.; Marre, M.; Holst, J.J.; Garber, A.; Baeres, F.M.; Thomsen, H.; Pratley, R.E. Comparison of the long-term effects of liraglutide and glimepiride monotherapy on bone mineral density in patients with type 2 diabetes. Endocr. Pract. Off. J. Am. Coll. Endocrinol. Am. Assoc. Clin. Endocrinol. 2016, 22, 406-411. [CrossRef]

39. Iepsen, E.W.; Lundgren, J.R.; Hartmann, B.; Pedersen, O.; Hansen, T.; Jorgensen, N.R.; Jensen, J.E.; Holst, J.J.; Madsbad, S.; Torekov, S.S. Glp-1 receptor agonist treatment increases bone formation and prevents bone loss in weight-reduced obese women. J. Clin. Endocrinol. Metab. 2015, 100, 2909-2917. [CrossRef]

40. Mabilleau, G.; Mieczkowska, A.; Chappard, D. Use of glucagon-like peptide-1 receptor agonists and bone fractures: A metaanalysis of randomized clinical trials. J. Diabetes 2014, 6, 260-266. [CrossRef]

41. Su, B.; Sheng, H.; Zhang, M.; Bu, L.; Yang, P.; Li, L.; Li, F.; Sheng, C.; Han, Y.; Qu, S.; et al. Risk of bone fractures associated with glucagon-like peptide-1 receptor agonists' treatment: A meta-analysis of randomized controlled trials. Endocrine 2015, 48, 107-115. [CrossRef]

42. Zhang, Y.S.; Weng, W.Y.; Xie, B.C.; Meng, Y.; Hao, Y.H.; Liang, Y.M.; Zhou, Z.K. Glucagon-like peptide-1 receptor agonists and fracture risk: A network meta-analysis of randomized clinical trials. Osteoporos. Int. 2018, 29, 2639-2644. [CrossRef] [PubMed]

43. Driessen, J.H.; van Onzenoort, H.A.; Starup-Linde, J.; Henry, R.; Burden, A.M.; Neef, C.; van den Bergh, J.P.; Vestergaard, P.; de Vries, F. Use of glucagon-like-peptide 1 receptor agonists and risk of fracture as compared to use of other anti-hyperglycemic drugs. Calcif. Tissue Int. 2015, 97, 506-515. [CrossRef] [PubMed]

44. Driessen, J.H.; Henry, R.M.; van Onzenoort, H.A.; Lalmohamed, A.; Burden, A.M.; Prieto-Alhambra, D.; Neef, C.; Leufkens, H.G.; de Vries, F. Bone fracture risk is not associated with the use of glucagon-like peptide-1 receptor agonists: A population-based cohort analysis. Calcif. Tissue Int. 2015, 97, 104-112. [CrossRef] [PubMed]

45. Nuche-Berenguer, B.; Lozano, D.; Gutierrez-Rojas, I.; Moreno, P.; Marinoso, M.L.; Esbrit, P.; Villanueva-Penacarrillo, M.L. Glp-1 and exendin-4 can reverse hyperlipidic-related osteopenia. J. Endocrinol. 2011, 209, 203-210. [CrossRef]

46. Kim, J.Y.; Lee, S.K.; Jo, K.J.; Song, D.Y.; Lim, D.M.; Park, K.Y.; Bonewald, L.F.; Kim, B.J. Exendin-4 increases bone mineral density in type 2 diabetic oletf rats potentially through the down-regulation of sost/sclerostin in osteocytes. Life Sci. 2013, 92, 533-540. [CrossRef]

47. Papazafiropoulou, A.; Papanas, N.; Pappas, S.; Maltezos, E. Role of endogenous glp-1 and its agonists in osteopenia and osteoporosis: But we little know until tried. Curr. Diabetes Rev. 2014, 10, 43-47. [CrossRef]

48. Chandran, M. Diabetes drug effects on the skeleton. Calcif. Tissue Int. 2017, 100, 133-149. [CrossRef]

49. Napoli, N.; Chandran, M.; Pierroz, D.D.; Abrahamsen, B.; Schwartz, A.V.; Ferrari, S.L.; Bone, I.O.F.; Diabetes Working, G Mechanisms of diabetes mellitus-induced bone fragility. Nat. Rev. Endocrinol. 2017, 13, 208-219. [CrossRef]

50. Egger, A.; Kraenzlin, M.E.; Meier, C. Effects of incretin-based therapies and sglt2 inhibitors on skeletal health. Curr. Osteoporos. Rep. 2016, 14, 345-350. [CrossRef]

51. Cai, T.T.; Li, H.Q.; Jiang, L.L.; Wang, H.Y.; Luo, M.H.; Su, X.F.; Ma, J.H. Effects of glp-1 receptor agonists on bone mineral density in patients with type 2 diabetes mellitus: A 52-week clinical study. BioMed Res. Int. 2021, 2021, 3361309. [CrossRef]

52. Kong, Q.X.; Ruan, Q.; Fan, C.; Liu, B.L.; Reng, L.P.; Xu, W. Evaluation of the risk of fracture in type 2 diabetes mellitus patients with incretins: An updated meta-analysis. Endokrynol. Pol. 2021, 72, 319-328. [CrossRef] [PubMed] 
53. Sciacqua, A.; Succurro, E.; Armentaro, G.; Miceli, S.; Pastori, D.; Rengo, G.; Sesti, G. Pharmacological treatment of type 2 diabetes in elderly patients with heart failure: Randomized trials and beyond. Heart Fail. Rev. 2021. [CrossRef] [PubMed]

54. Kitaura, H.; Ogawa, S.; Ohori, F.; Noguchi, T.; Marahleh, A.; Nara, Y.; Pramusita, A.; Kinjo, R.; Ma, J.; Kanou, K.; et al. Effects of incretin-related diabetes drugs on bone formation and bone resorption. Int. J. Mol. Sci. 2021, 22, 6578. [CrossRef] [PubMed] 